Article

\title{
Combination of $A \beta$ Secretion and Oxidative Stress in an Alzheimer-Like Cell Line Leads to the Over-Expression of the Nucleotide Excision Repair Proteins DDB2 and XPC
}

\author{
Anne Forestier, Thierry Douki, Viviana De Rosa, David Béal and Walid Rachidi * \\ Laboratoire Lésions des Acides Nucléiques, Université Joseph Fourier-Grenoble 1/CEA/Institut \\ Nanoscience et Cryogénie/SCIB, UMR-E3, Grenoble, France; \\ E-Mails: ann.forestier@gmail.com (A.F.); thierry.douki@cea.fr (T.D.); \\ viviana.derosa@ibb.cnr.it (V.D.R.); david.beal@cea.fr (D.B.) \\ * Author to whom correspondence should be addressed; E-Mail: walid.rachidi@cea.fr; \\ Tel.: +33-438-785-011; Fax: +33-438-785-090.
}

Academic Editor: G. Jean Harry

Received: 7 May 2015 / Accepted: 29 June 2015 / Published: 30 July 2015

\begin{abstract}
Repair of oxidative DNA damage, particularly Base Excision Repair (BER), impairment is often associated with Alzheimer's disease pathology. Here, we aimed at investigating the complete Nucleotide Excision Repair (NER), a DNA repair pathway involved in the removal of bulky DNA adducts, status in an Alzheimer-like cell line. The level of DNA damage was quantified using mass spectrometry, NER gene expression was assessed by qPCR, and the NER protein activity was analysed through a modified version of the COMET assay. Interestingly, we found that in the presence of the Amyloid $\beta$ peptide $(A \beta)$, NER factors were upregulated at the mRNA level and that NER capacities were also specifically increased following oxidative stress. Surprisingly, NER capacities were not differentially improved following a typical NER-triggering of ultraviolet C (UVC) stress. Oxidative stress generates a differential and specific DNA damage response in the presence of $A \beta$. We hypothesized that the release of NER components such as DNA damage binding protein 2 (DDB2) and Xeroderma Pigmentosum complementation group $\mathrm{C}$ protein (XPC) following oxidative stress might putatively involve their apoptotic role rather than DNA repair function.
\end{abstract}


Keywords: neurodegenerative disorders; Alzheimer's disease; DNA damage; DNA repair; nucleotide excision repair; XPC; DDB2; oxidative stress

\section{Introduction}

Alzheimer's disease (AD) is the most common neurodegenerative disease, which progressively leads to massive neuronal death. The physiopathology of $\mathrm{AD}$ is characterized by two pathological hallmarks: within neurons, the accumulation of hyperphosphorylated Tau protein leads to the formation of neurofibrillary tangles [1]; in the extraneuronal environment, the abnormal proteolytic processing of the amyloid precursor protein (APP) leads to the aggregation of senile plaques, or amyloid plaques. $\mathrm{AD}$ brains exhibit a massive apoptosis, which is known to be a cellular response to excess DNA damage that triggers a programmed cell death mechanism [2]. The link between AD and accumulation of DNA damage has led several groups to study the DNA repair capacities in AD patients, mouse models and cell lines and, as a general trend, a lower ability to maintain genomic integrity was observed [3-11].

Cells possess several DNA repair pathways, each of them is in charge of a specific class of lesions. The base excision repair (BER) pathway is preferentially involved in removing and replacing either methylated, oxidized or deaminated (uracil) bases and single strand breaks [12]. Nucleotide excision repair (NER) is predominantly involved in the repair of bulky adducts, such as UV-induced photoproducts, adducts to chemicals and DNA-DNA or DNA-protein crosslinks [13]. NER actually consists of two sub-pathways: Global Genome Repair (GG-NER) and Transcription-Coupled Repair (TC-NER). GG-NER surveys the whole genome while TC-NER removes RNA Polymerase-blocking lesions in transcribed strands of active genes [14]. Other pathways, homologous recombination (HR) and non-homologous end joining (NHEJ) are in charge of the repair of double strand breaks (DSB) [15].

However, the DNA repair can be impaired, and thus involved in many of pathologies. The most obvious consequence is an increased susceptibility to cancer because of accumulation of mutations. Yet, decreased DNA repair capacities are also involved in neurological disorders, as illustrated by a series of genetic diseases that impact the nucleotide excision repair. The best known example is Xeroderma Pigmentosum (XP) and its seven XPA to XPG subgroups corresponding to the associated mutated NER enzyme [16]. If the main feature of the XP disease is the high susceptibility to develop skin cancers, neurodegeneration could be observed in some cases (XPA, XPB, XPF, XPG) [17]. Cockayne's Syndrome (CS), another autosomal recessive congenital disorder, characterized by mutations in transcription-coupled NER enzymes CSA and CSB, leads to a defective development of the central nervous system (CNS), a high sensitivity to sunlight and a premature aging [18]. Association of NER and Alzheimer's disease has been poorly studied, while a few papers suggest that the mechanisms underlying neurological impairment in XP or CS could be similar to those involved in $\mathrm{AD}[19]$.

It may be added that although data have been gathered on the reduced DNA repair capacities in $A D$, no real mechanistic investigation has been made to explain this result. We previously showed that the secretion of the $\mathrm{AD}$-specific neurotoxic peptide $\mathrm{A} \beta$ in a neuroblastoma cell line led to an overall 
decrease of BER, either at the basal level or following oxidative stress [20]. The present work aimed at extending the work to NER, first because of the link between neuronal disorders and deficiency in this repair pathway. In addition, oxidative stress not only induces breaks and oxidized damages but may also lead to bulky lesions that are likely substrates for NER. For this purpose, we studied the repair of pyrimidine dimeric photoproducts induced by UVC radiation and quantified the expression of a series of genes in an Alzheimer-like cell line. The obtained results led us to propose a role outside of repair in AD for some NER proteins.

\section{Results}

\subsection{UVC-Induced Cytotoxicity Is Similar in Mock and APP751-Expressing Cells at Low Doses}

To assess short and long-term toxicity following exposure to UVC, we used the MTT (Figure 1A) and clonogenicity (Figure 1B,C) assays. Four doses of UVC irradiation were tested. At $5 \mathrm{~J} / \mathrm{cm}^{2}$, the mock and APP751 cell lines exhibited similar viability (79.4\% versus $78 \%$ respectively). At the same dose, the clonogenic potential was $63.5 \%$ for mock and $64.7 \%$ for APP 751 . At $10 \mathrm{~J} / \mathrm{cm}^{2}$, the mock cell line appeared to be more sensitive to UVC irradiation with a survival of $24 \%$ against $51.8 \%$ for the APP751-expressing cells $(p=0.0001)$. However, the $10 \mathrm{~J} / \mathrm{cm}^{2}$-associated clonogenic potential was similar in the two cell lines (39.1\% for mock and 46.2\% for APP751). After $15 \mathrm{~J} / \mathrm{cm}^{2}$ irradiation the mock viability was more affected (23.3\% left) than the APP751-expressing cells $(35.4 \%, p=0.04)$ although the clonogenic potential was not significantly different between mock and APP751 (17.9\% and $32.7 \%$, respectively). At $20 \mathrm{~J} / \mathrm{cm}^{2}$, the mock cell line was once again more sensitive to irradiation than the APP751 cells with a residual survival of $16.1 \%$ and $24.2 \%$ respectively $\left(p=4 \times 10^{-5}\right)$. Clonogenic potential was not more affected in one cell line compared to the other. As the lowest irradiation dose $\left(5 \mathrm{~J} / \mathrm{cm}^{2}\right)$ did not induce significant difference in either MTT or in vitro colony forming assays between the two cell lines, it was chosen for further studies.

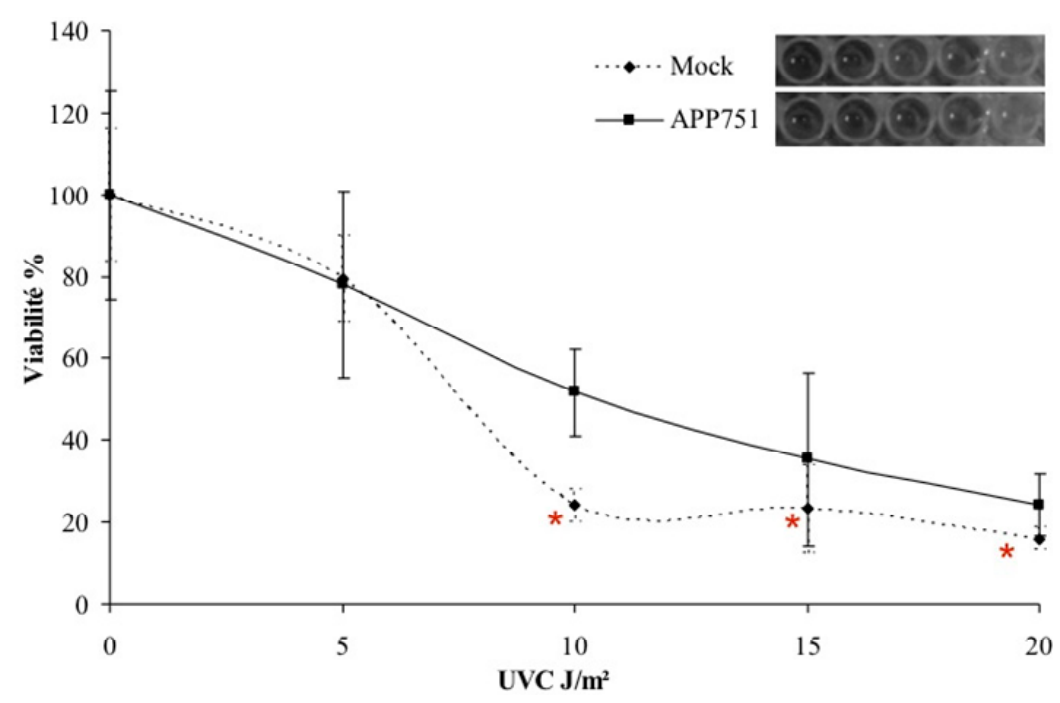

(A)

Figure 1. Cont. 


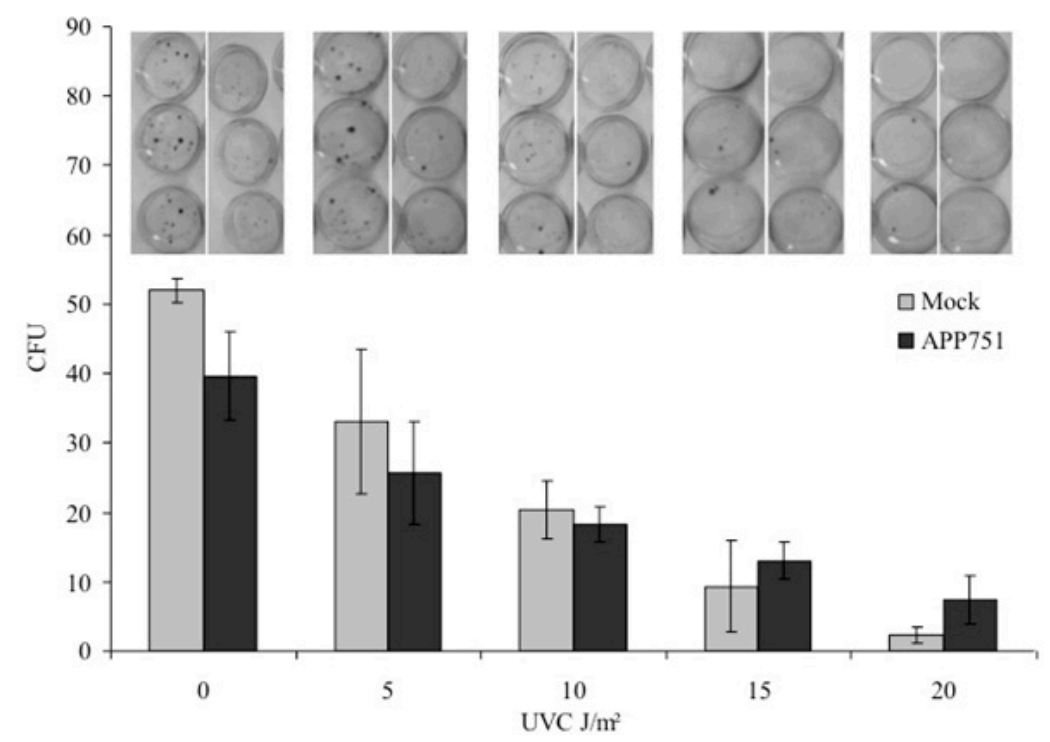

(B)

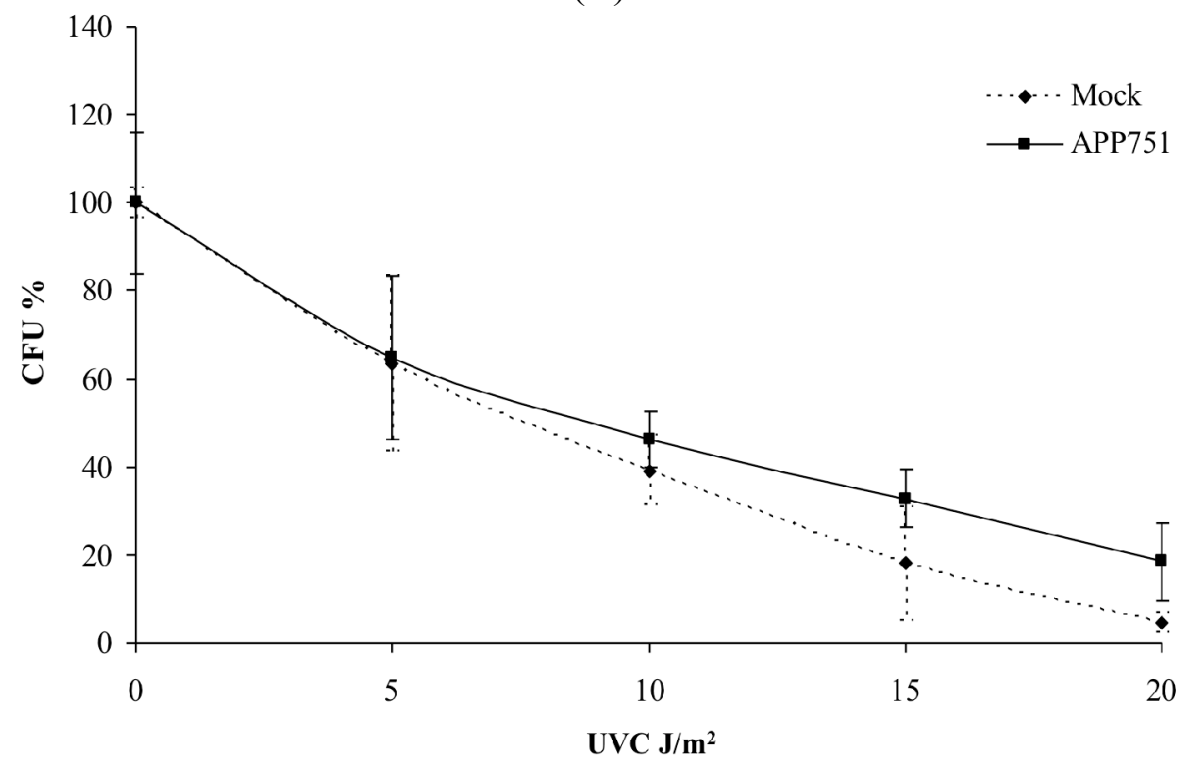

(C)

Figure 1. UVC cytotoxicity at short and long-term. Mock and APP751-expressing cells were cultured $48 \mathrm{~h}$ prior to irradiation. Then, four doses of UVC 5, 10, 15 and $20 \mathrm{~J} / \mathrm{m}^{2}$ were tested. For short-term cytotoxicity, cells were grown for additional $24 \mathrm{~h}$ and then the MTT assay was performed to assess cell viability (A). Significance was assessed through the Student $t$-test $(n=3)$. * Data significantly different from mock cells $(p<0.05)$; For long-term toxicity, the cells were grown for an additional 12 days and then the colonies were revealed using crystal violet, and manually counted. The bar graph represents the number of colony forming units $(\mathrm{CFU})$ in relation to the dose used; a representative picture of petri dishes following revelation with crystal violet is given above each bar of the graph, corresponding to each tested condition in triplicate $(\mathbf{B})$; $(\mathbf{C})$ represents the evolution of CFU in percentage Significance assessed through the Student $t$-test $(n=3)$. 
2.2. Effect of $\mathrm{A \beta}, \mathrm{H}_{2} \mathrm{O}_{2}$ Treatment, and UVC Radiation on the NER-Associated Gene Expression in Mock and APP751-Expressing Cells

\subsubsection{Basal NER-Associated Gene Expression in the Mock and APP751-Expression Cells}

The expression levels of DNA repair enzymes were measured using real-time quantitative PCR, which allows for the relative quantification of the expression of a target gene under one condition compared to another by normalizing to one or more housekeeping genes that are considered stably expressed in both conditions. We first investigated the expression level of NER-associated genes between the mock and the APP751-expressing cell lines under basal conditions without any exogenous stress (Figure 2A). The expression ratio of XPA, XPC, DDB1, DDB2, CSB and ERCC1 mRNA levels were not significantly different between the two cell lines. In contrast, the expression ratio of CSA was lower in the APP751-expresing cells compared to the mock ones $(0.54 \pm 0.04, p=0.04)$. The fold change in expression in APP751-expressing cells compared to mock-transfected cells for XPD was $0.67 \pm 0.19(p=0.0007)$. The expression of XPB changed $0.71 \pm 0.26$-fold in APP751-expressing cells compared to mock-transfected cells $(p=0.02)$.

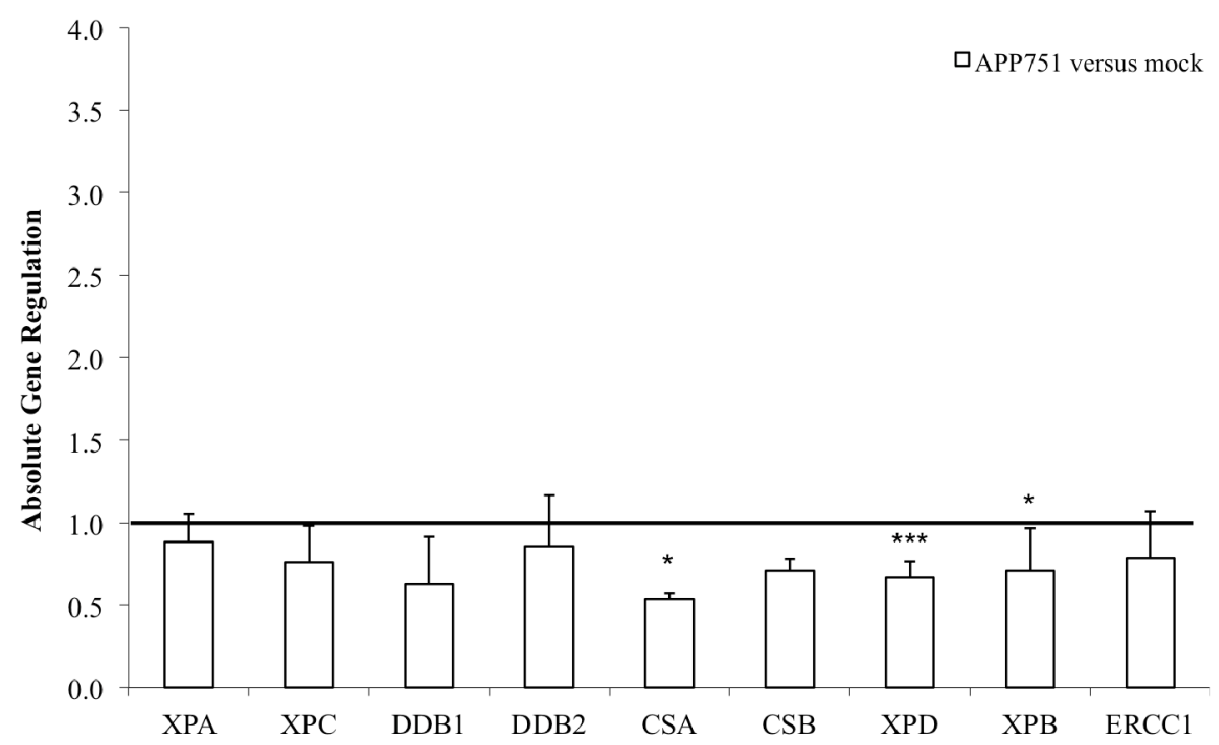

(A)

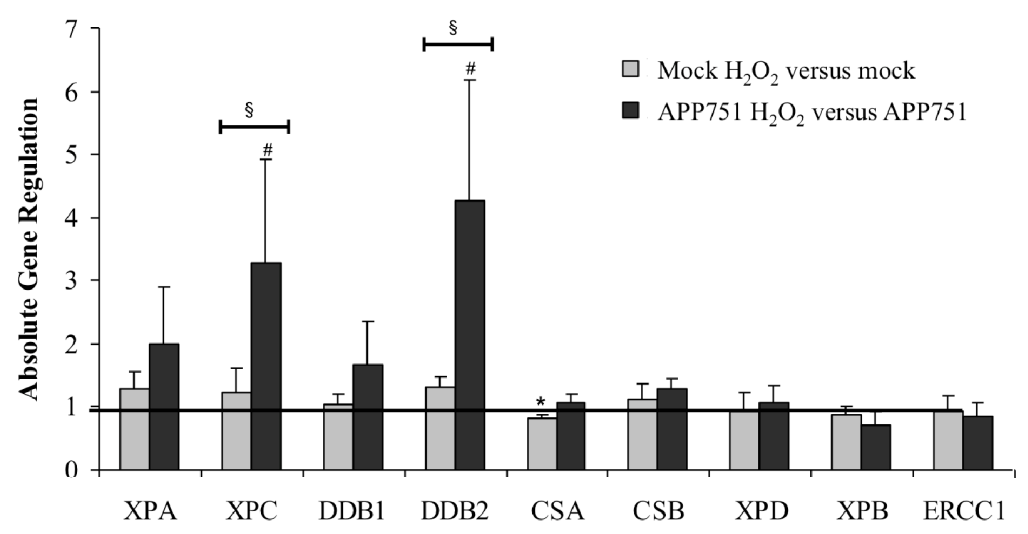

(B)

Figure 2. Cont. 


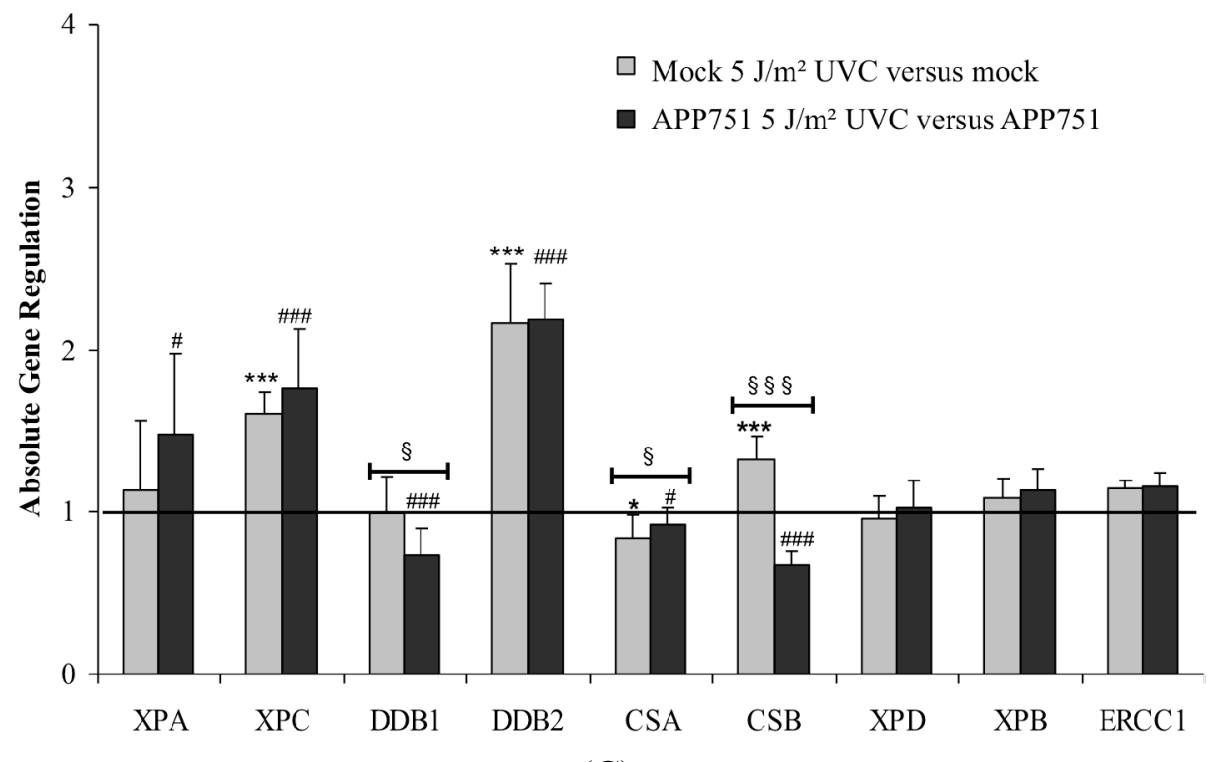

(C)

Figure 2. $\mathrm{A} \beta, \mathrm{H}_{2} \mathrm{O}_{2}$, and UVC-induced NER gene expression. Mock and APP751-expressing cell lines were cultured for $48 \mathrm{~h}$ and left untreated $(\mathbf{A})$ or $\mathrm{H}_{2} \mathrm{O}_{2}$-treated $(115 \mu \mathrm{M})(\mathbf{B})$ or UVC-irradiated $\left(5 \mathrm{~J} / \mathrm{m}^{2}\right)(\mathbf{C})$. Total RNA was extracted and subsequently reverse-transcribed. A total of $20 \mathrm{ng}$ of corresponding cDNA were used to detect specific gene expression using real-time qPCR. Gene expression was investigated in APP751-expressing versus mock cells $(\mathbf{A}, n=7), \mathrm{H}_{2} \mathrm{O}_{2}$-treated cells versus untreated cells $(\mathbf{B}, n=3)$ or UVC-irradiated cells versus untreated cells $(\mathbf{C}, n=3)$. The mean of the corresponding expression ratios was calculated, and a Student's $t$-test was performed. * data significantly different $(p<0.05)$ from mock cells, *** $p<0.0005$; ${ }^{*}$ data significantly different $(p<0.05)$ from APP751-expressing cells, ${ }^{\# \#} p<0.0005$ and ${ }^{\S}$ data significantly different $(p<0.05)$ from each other, ${ }^{\S \S} p<0.0005$.

Under basal condition (without any exogenous stress), the expression of most NER-associated genes was not significantly different between mock and APP751-expressing cells.

\subsubsection{Effect of $\mathrm{H}_{2} \mathrm{O}_{2}$ Treatment on NER-Associated Gene Expression in Mock and APP751 Cell Lines}

We then examined the gene expression profile of the two cell lines following $\mathrm{H}_{2} \mathrm{O}_{2}$-induced oxidative stress (Figure 2B). The expression profiles of XPA, DDB1, XPD, XPB, CSB and ERCC1 were not significantly modified in both cell lines. In contrast, the expression ratio of CSA was diminished within the mock cell line following $\mathrm{H}_{2} \mathrm{O}_{2}$ exposure $(0.83 \pm 0.04, p=0.02)$. After $\mathrm{H}_{2} \mathrm{O}_{2}$ treatment, XPC was not significantly modulated in the mock cell line, while it was over-expressed by the APP751 cell line $(1.99 \pm 0.92, p=0.03)$. This difference in XPC expression was not only observed when comparing one treated cell line with its own control but also when comparing the two treated cell lines $(p=0.05)$. DDB2 mRNA level was slightly but significantly upregulated in the mock cell line $(1.31 \pm 0.15, p=0.01)$. This trend was much more pronounced in the APP751-expressing cell line (4.28 $\pm 1.91, p=0.02)$ after $\mathrm{H}_{2} \mathrm{O}_{2}$-induced oxidative stress. These expression ratios were also significantly different when the two treated cell lines were compared $(p=0.03)$. 
Following $\mathrm{H}_{2} \mathrm{O}_{2}$ treatment, the expression profile was significantly different for several NER factors between the two cell lines. As the most salient features, XPC and DDB2 were upregulated in APP751-expressing cells compared to mock one, indicating an A $\beta$-dependent activation of these two factors following $\mathrm{H}_{2} \mathrm{O}_{2}$ treatment.

\subsubsection{Effect of UVC Radiation on the NER-Associated Gene Expression in Mock and} APP751-Expressing Cells

Next, we compared NER gene expression profiles between the two cell lines following exposure to $5 \mathrm{~J} / \mathrm{m}^{2}$ of UVC radiation (Figure 2C). XPA mRNA expression levels were not significantly modified in the mock cell line following irradiation, while it was upregulated in APP751-expressing cells $(1.48 \pm 0.49, p=0.03)$. However, these ratios were not significantly different when the two irradiated cell lines were compared. XPC was significantly over-expressed in both mock and APP751 cell lines (1.61 $\pm 0.13, p=1 \times 10^{-9}$ and $1.76 \pm 0.36, p=0005$ respectively) and these ratios were not significantly different from each other. The same scheme was observed for DDB2 with an increase in expression of $2.15 \pm 0.37$-fold for the mock cell line $\left(p=2 \times 10^{-7}\right)$ and of $2.18 \pm 0.22$-fold for the APP751 cell line $\left(p=1 \times 10^{-6}\right)$, these two UVC-induced upregulation being not significantly different from each other. Expression of DDB1 was not modified after UVC-irradiation in the mock cell line but it was significantly downregulated $(0.73 \pm 0.17, p=0.002)$ in the APP751-expresing cell line. UVC irradiation did not induce any modulation within the mock or APP751-expressing cells, and accordingly no differences between the two cell lines for XPD, XPB or ERCC1. However, the expression ratio of CSA was reduced following UVC irradiation within both mock and APP751-expressing cells $(0.84 \pm 0.14, p=0.05 ; 0.92 \pm 0.10, p=0.03$, respectively). CSB was upregulated within the mock cells $\left(1.32 \pm 0.14, p=2 \times 10^{-5}\right)$ and downregulated within the APP751-expressing cells $\left(0.67 \pm 0.08, p=6 \times 10^{-8}\right)$.

The expression profile following UVC-induced stress was not different between mock and APP751-expressing cells. XPC and DDB2 were both over-expressed under the same extent, indicating that $\mathrm{A} \beta$ does not influence the activation of these two factors following UVC exposure.

\section{3. $\mathrm{H}_{2} \mathrm{O}_{2}$ Treatment Specifically Enhances Excision Capacity of UVC Lesions by the APP75I Cell Line}

We used a comet-based assay to determine the efficiency of the NER system in our cell lines following $\mathrm{H}_{2} \mathrm{O}_{2}$ treatment. In this approach, UVC-irradiated nuclei from cells, used as substrate are incubated with protein extracts of the cells of interest. Excision of photoproducts by NER proteins induces additional breaks revealed by the Comet analysis (Figure 3). We first checked that the excision capacity of our cell extracts was significantly higher than the excision capacity of reaction buffer alone. Actually, the mean tail intensity of the UVC-damaged genomic substrates after exposure to cellular extracts was significantly higher than the tail intensity after incubation with reaction buffer alone, depicting a damage-specific incision by the cell extracts. We then showed that $\mathrm{H}_{2} \mathrm{O}_{2}$ treatment did not induce an increase in excision capacity within the mock cell line $(22.35 \%$ for the control and $20.49 \%$ tail intensity after $\mathrm{H}_{2} \mathrm{O}_{2}$ treatment). In contrast, we observed that the excision capacity of the 
APP751 cell line that corresponds to $22.30 \%$ tail intensity under basal conditions increased to $37.45 \%$ $\left(p=3 \times 10^{-6}\right)$ after exposure to $\mathrm{H}_{2} \mathrm{O}_{2}$.

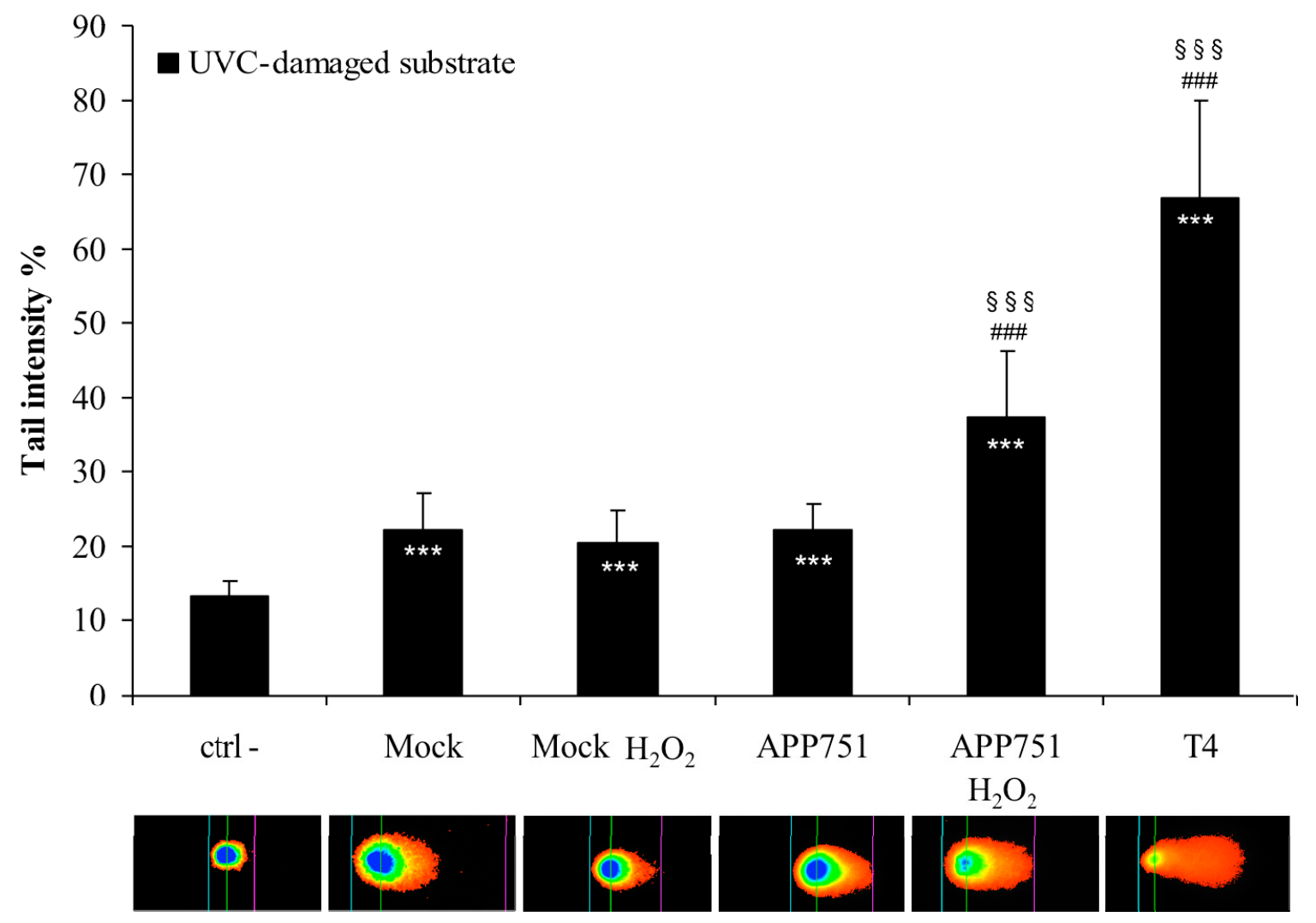

Figure 3. Analysis of photoproducts excision activity after $\mathrm{H}_{2} \mathrm{O}_{2}$ treatment. Mock and APP751-expressing cells were cultured for $48 \mathrm{~h}$ and either left untreated or incubated with $\mathrm{H}_{2} \mathrm{O}_{2}(115 \mu \mathrm{M})$ in the cell culture media for an additional $24 \mathrm{~h}$. Total cell extracts were generated, and photoproducts excision capacity was analyzed on damaged genomic DNA substrates for 30 min using a modified version of the comet assay. The excision capacity of cell extracts was analyzed as the mean tail intensity of the comet. Three biological replicates were tested in triplicate in three independent experiments. The mean tail intensity of each cell extract $(n=3)$ was calculated and then a Student's $t$-test was performed. Ctrl-: negative control (corresponds to the reaction buffer alone). T4: T4-endonuclease, positive control for the excision of the UV-induced DNA damage; $* \#$ data significantly different from Ctrl-, $* * *(p=0.0005) ;{ }^{\# \#}(p=0.0005) ;{ }^{\S \S \S}(p=0.0005)$.

Thus, the photoproducts excision activity of cell extracts following $\mathrm{H}_{2} \mathrm{O}_{2}$-induced stress seems to be $A \beta$-dependent.

\subsection{UVC Irradiation Induces a Similar Increase of Excision Capacity of UVC Lesions in Both Mock and APP751 Cell Lines}

We further wanted to assess the excision capacity on UVC-damaged substrate of our cell extracts, following UVC irradiation (Figure 4). The excision capacity was significantly increased in both mock (from $22.15 \%$ under basal conditions to $37.22 \%$ tail intensity after irradiation, $p=0.0004$ ) and 
APP751-expressing cells (from $19.26 \%$ to $31.92 \%$ tail intensity, $p=0.0001$ ). No significant difference in terms of excision capacity was found between UVC-irradiated mock and UVC-irradiated APP751 cells.

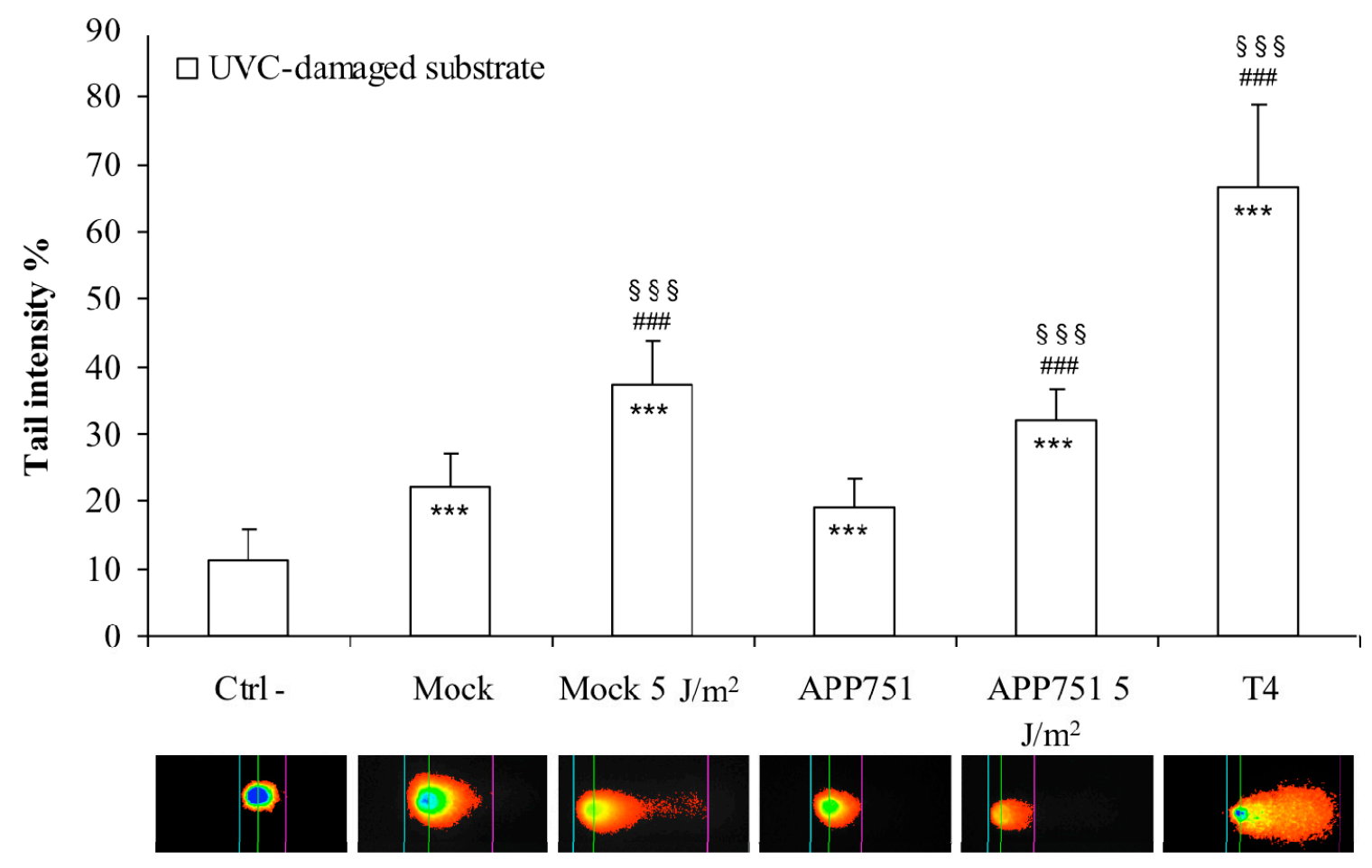

Figure 4. Analysis of photoproducts excision activity after UVC irradiation. Mock and APP751-expressing cells were cultured for $48 \mathrm{~h}$ and either left untreated or UVC-irradiated. Total cell extracts were generated, and photoproducts excision capacity was analyzed on damaged genomic DNA substrates for 30 min using a modified version of the comet assay. The excision capacity of cell extracts was analyzed as the mean tail intensity of the comet. Three biological replicates were tested in triplicate in three independent experiments. The mean tail intensity of each cell extract $(n=3)$ was calculated and then a Student's $t$-test was performed. Ctrl-corresponds to reaction buffer alone. T4: T4-endonuclease, positive control for the excision of the UV-induced DNA damage; *\#§ data significantly different

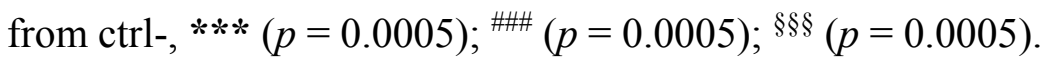

The photoproducts excision capacity following UVC-irradiation is not influenced by A $\beta$.

\subsection{Assessments of the Photoproducts Repair Kinetics in the Mock and APP751-Expressing Cells with} or without $\mathrm{H}_{2} \mathrm{O}_{2}$ Pre-Treatment

We first wanted to assess the repair kinetics of cyclobutane pyrimidine dimers in our two cell lines, following $5 \mathrm{~J} / \mathrm{m}^{2} \mathrm{UVC}$ irradiation. Four hours after irradiation, the residual photoproducts percentage was not significantly different between the mock and APP751-expressing cells (Figure 5A): the level of thymine-thymine Cyclobutane Pyrimidine Dimers TT-CPD was $84 \%$ for mock and $82 \%$ for APP751; residual thymine-cytosine CPD (TC-CPD) was 69\% for mock and 74\% for APP751; and finally residual cytosine-thymine CPD (CT-CPD) was 37\% for mock and 36\% for APP751-expressing cells. Twenty-four hours after UVC irradiation, the level of residual CPD was also similar in the two 
cell lines. For mock and APP751 respectively, the level of TT-CPD was 47\% and 44\%, TC-CPD 29\% and $24 \%$ and then CT-CPD $11 \%$ and $10 \%$.

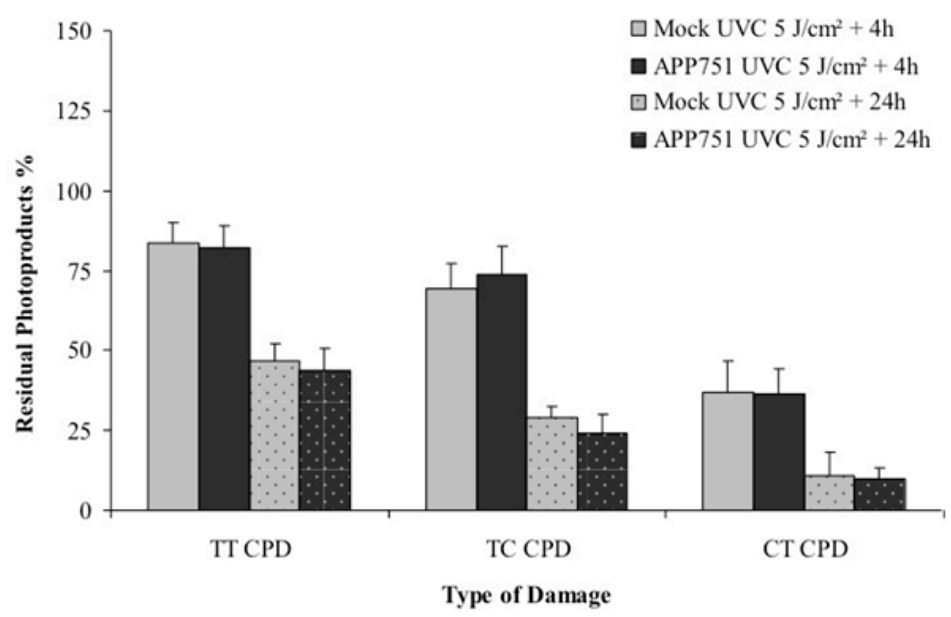

(A)

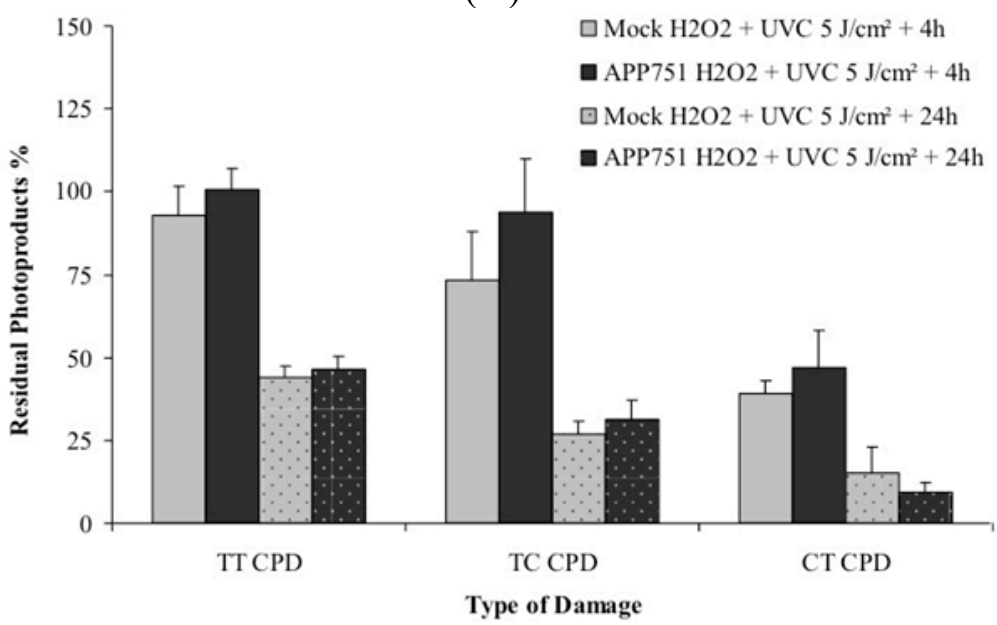

(B)

Figure 5. Assessments of the photoproducts repair kinetics in the mock and APP751-expressing cells. Persistence of cyclobutane dimers within Mock and APP751-expressing cells exposed to $\mathrm{UVC}\left(5 \mathrm{~J} / \mathrm{m}^{2}\right)$ radiation without (A) or with $\mathrm{H}_{2} \mathrm{O}_{2}$ pre-treatment (B). Repair of TT CPD, TC CPD and CT CPD are shown. The results are expressed in percentage of residual lesions and are the average \pm SD of data obtained with three experiments.

We then wanted to assess whether a $\mathrm{H}_{2} \mathrm{O}_{2}$ exposure prior to UVC irradiation would have an effect on CPD repair kinetics (Figure 5B). Four hours after irradiation, the level of any CPD was not significantly different between the two cell lines. The residual TT-CPD was 93\% versus $101 \%$, TC-CPD 73\% versus 94\% and CT-CPD 39\% versus 47\% for mock versus APP751-expressing cells respectively. Twenty-four hours after UVC irradiation, the level of the residual photoproducts was not either significantly different between the two cell lines. The residual TT-CPD level was $44 \%$ for mock and $46 \%$ for APP751, for TC-CPD it was $27 \%$ for mock and $31 \%$ for APP751 and finally for CT-CPD it was $15 \%$ for mock and 9\% for APP751. 
These results indicate that even though $\mathrm{H}_{2} \mathrm{O}_{2}$ treatment was shown to stimulate DDB2 and XPC gene expression, pre-incubating cells with $\mathrm{H}_{2} \mathrm{O}_{2}$ prior to UVC exposure does not influence the UVC-damage repair kinetics.

\section{Discussion}

Alzheimer's disease is characterized by two major protein abnormalities. One of them involves the hyperphosphorylation of the microtubule-associated Tau protein and the other is the production and extracellular aggregation of the neurotoxic peptide $A \beta[1]$.

DNA repair impairment is involved in both carcinogenesis and neurodegenerative disorders [21]. Given the high oxygen consumption of the brain, the high concentrations of polyunsaturated fatty acids that are highly susceptible to lipid peroxidation, its elevated content in redox active metals and the capacity of $\mathrm{A} \beta$ to generate reactive oxygen species, $\mathrm{AD}$ neurons are especially sensitive to oxidative stress [22]. As a matter of fact, these AD neurons exhibit increased oxidative damage to DNA [23]. ROS can lead to three type of DNA damage: small damaged bases, bulky helix distorting adducts and strand breaks [24]. A growing number of publications reveal that the small damaged bases and single strand breaks-associated DNA repair pathway, BER, is strongly diminished in the presence of A $\beta$ although oxidative DNA damage was elevated [5]. While BER has been quite widely investigated in AD-associated studies, NER, in contrast, has been poorly analysed though its impairment could play a major role in the disease. Although BER and NER have been considered as harshly distinct and isolated pathways for a long time, this consensus has evolved over the past few years. Actually, numerous studies revealed that the compartmentalization of these two excision/synthesis pathways might not be so strict. A few oxidative lesions, mostly repaired by BER, are also repaired by XP proteins [25]. XPC (in addition to its role in NER pathway) could play an important role against oxidative stress. In favour of a protective role of XPC against oxidative DNA damage, it has been shown that XPC cells are hypersensitive to the killing effects of DNA-oxidizing agents due to the accumulation of oxidative DNA damage [26]. The protective function of XPC has been ascribed to its ability to affect the key BER enzymes such as thymine DNA and 8-oxoguanine DNA glycosylases. An in vitro study showed that 8oxoG-bearing oligonucleotides undergo an incision through a reconstituted NER system [27]. According to Yang [28], the interplay between NER and BER is not a matter of competition but rather of complementary and cooperative actions. Furthermore, the 8oxoG-specific glycosylase OGG1 activity is stimulated by the XPC/hHR23B complex [26,29]. In XPA-deficient cells, $\mathrm{H}_{2} \mathrm{O}_{2}$-induced DNA damage is repaired less efficiently than in normal cells [30]. CS proteins are also involved in oxidative stress-induced DNA damage. Cells from CS patients are extremely sensitive to oxidative stress [31-33], indicating that CSA or CSB-deficient cells are unable to repair oxidative damage.

The involvement of NER factors in the repair of oxidative damage constitute a hypothesis that could explain the phenomena of neurodegeneration in DNA repair-associated hereditary diseases such as Xeroderma Pigmentosum and Cockayne Syndrome [34]. By extension, NER impairment could also be involved in Alzheimer's disease.

In our study we used two neuroblastoma cell lines either transfected with the pcDNA3 plasmid alone (mock cell line), or bearing the APP751 transgene (APP751-expressing cell line). The APP751 
mutation corresponds to a double missense mutation, which was first highlighted in a Swedish family, and results in an increased secretion of $A \beta$ at physiologically relevant levels.

We first compared NER-associated gene expression under basal conditions, without any exogenous stress, between the mock and APP751-expresing cell line. We observed that XPD and XPB were down regulated in the APP751-expressing cells compared to the mock cell line. This first observation counteracts previous published data indicating that the protein expression of these two helicases is increased in AD-affected human brains [35]. This difference in findings could be explained by the time of $\mathrm{A} \beta$ exposition undergone by the two distinct analysed samples. In Hermon's study the samples came from AD patients whose neurons suffered the deleterious effects of $A \beta$ for years. In our study, the APP751-expressing cells had been exposed to $A \beta$ for only $48 \mathrm{~h}$. As it is underlined by many publications, reduced DNA repair might be an early event in the etiology of AD [19] which correlates the mRNA down-regulation of XPB and XPD we observed. Over a certain threshold of DNA damage, as in Hermon's study, the cell might set off a last rescue attempt to repair its DNA, which could explain the protein over-expression of XPD and XPB. More likely, these two helicases might not be involved in NER but in p53-mediated apoptosis as it was previously shown [36]. In APP751-expressing cells compared to mock under basal conditions, CSA mRNA expression was decreased. As we mentioned previously, a deficiency in CSA or CSB increases cell sensitivity to oxidative stress.

We then applied an oxidative stress and compared the resulting modulation of NER gene expression in our two cell lines. As anticipated, the mock cell line did not modulate NER gene expression after $\mathrm{H}_{2} \mathrm{O}_{2}$ exposition because oxidative DNA lesions mostly consist in small base damage and single strand breaks. Unexpectedly, the APP751-expressing cell line over-expressed genes like XPC or DDB2, which are associated with the repair of UV-induced damage by GG-NER. In order to gain further insights in the role of NER, we investigated the effect of a stress leading to DNA damage handled by the repair pathway, and chose UVC. Although not biologically relevant, UVC has the great advantage of avoiding addition of chemicals to damage DNA and of corresponding to very short treatment with minimal handling of the cells. So, we exposed the mock and APP751 cell lines to UVC and analysed the expression of the same set of NER genes as following $\mathrm{H}_{2} \mathrm{O}_{2}$-treatment. We showed that the two cell lines exhibited a similar modulation of the expression pattern upon UVC-irradiation with overexpression of the same NER genes, especially XPC and DDB2.

We then wanted to assess whether the differences observed in gene expression profiles was also encountered at the protein activity level. Thus we used a comet-based assay, allowing the quantification of the excision capacity of cell extracts, on UVC-induced damaged genomic substrate. When analysing $\mathrm{H}_{2} \mathrm{O}_{2}$-treated cells, we found no increase in excision capacity between untreated mock and $\mathrm{H}_{2} \mathrm{O}_{2}$-treated mock. On the contrary, exposure to $\mathrm{H}_{2} \mathrm{O}_{2}$ lead to a significant increase within the APP751-expressing cells, depicting the fact that the overexpression of NER genes such as XPC and DDB2 following an oxidative stress helped the A $\beta$-secreting cell line to enhance its capacity to excise UVC-induced bulky lesions. We then compared the evolution of UVC-induced damage excision capacity between the two cell lines following UVC irradiation. Here we found the same increase in excision capacity in both mock and APP751-expressing cells, data consistent with the same NER gene expression patterns. These latter results suggest that an oxidative stress could specifically enhance NER capacities through DDB2 and XPC over-expression. 
For a better understanding of our results, we then hypothesized that exposure of cells to $\mathrm{H}_{2} \mathrm{O}_{2}$ prior to UVC irradiation could possibly stimulate APP751-cells and make them more competent for repairing UVC damage, as $\mathrm{H}_{2} \mathrm{O}_{2}$ treatment conferred upon them an enhanced photoproduct excision capacity according to the comet-based assay. This time, we used mass spectrometry lesion detection to perform a kinetic measurement of three photoproducts (TT-CPD, TC-CPD and CT-CPD). Unexpectedly, we found no significant differences in any of the CPD repair velocities, between the mock and APP751-expressing cells. It should be noted however that UVC increases expression of NER genes in the two cell lines. Thus, the specific effect of $\mathrm{H}_{2} \mathrm{O}_{2}$ on the repair of CPDs in APP751 cells could have been overwhelmed by the non-specific induction of BER by UVC radiation.

A first examination of these results could lead to the conclusion that the presence of $A \beta$ leads to an increase in NER activity upon oxidative stress and thus may be somewhat protective. As we already mentioned, some NER factors are involved in the repair of small oxidative DNA damage usually repaired by BER. The mRNA upregulation we observed might also possibly be due to the recognition of another kind of oxidative damage. Indeed, even if they constitute only a small fraction of ROS-induced DNA damage, oxidative bulky adducts have been identified in model systems and isolated DNA and could be tremendously deleterious to the cell because they are more likely to directly trigger apoptosis than small base damage [37]. To explain the phenomenon of neurodegeneration observed in XP and CS patients, Robbins hypothesized that a hypothetic bulky lesion might occur in neurons, a cell type undergoing extensive oxidative stress. Without efficient NER, these hypothetic DNA damage may accumulate in neurons and lead to apoptosis [38]. Cyclopurines and tandem lesions could match the position of the hypothetic DNA damage, the latter being moreover weakly repaired by BER [39]. Another kind of bulky lesions could result from the addition of the breakdown products of lipid peroxidation such as 4-hydroxynonenal (HNE), another consequence of the oxidative stress triggered by $\mathrm{A} \beta$ [1]. It is important to note that lipid peroxidation occurs as an early event in the brain but also in peripheral tissues of AD patients [40].

Yet, this improvement of NER upon oxidative stress in the presence of $A \beta$ is not completely satisfactory as an explanation to our observations following $\mathrm{H}_{2} \mathrm{O}_{2}$-treatment of APP751 cell lines. Indeed, an increase in NER pathway results in overexpression of a wider array of genes, as illustrated in the case of UVC irradiation. In contrast, only DDB2 and XPC are concerned by the effect of $\mathrm{H}_{2} \mathrm{O}_{2}$. Consequently, only the GGR part of NER is involved in this response, as seen in the activity measurements based on Comet assay. Indeed, DDB2 and XPC are DNA damage sensors in this repair sub-pathway. Yet this improved GGR activity in $\mathrm{H}_{2} \mathrm{O}_{2}$-treated APP751 cells is lower than that induced by the bulky pyrimidine dimers resulting from UVC irradiation as shown by the in cellulo measurements of CPD in combined $\mathrm{H}_{2} \mathrm{O}_{2} / \mathrm{UVC}$ experiments. It may be added that global genome repair is not an important mechanism in non-dividing cells like neurons. Accumulation of damage is mostly a concern in transcribed genes where it may inhibit synthesis of proteins or lead to impaired functionality. Accordingly, most links between DNA repair and neurodegenerative diseases are related to TCR [41].

This discussion invites us to look at the other putative roles of DDB2 and XPC. These proteins are mostly known for their participation in NER, as UVC-induced damaged sensors [42] but a growing number of publications suggest a role in DNA damage-induced apoptosis, not necessarily following a UV stress (reviewed in [43]). Actually, Stoyanova et al. [44] showed that DDB2 was required for DNA damage-induced apoptosis, following exposure to DNA damaging agents such as cisplatin [45]. 
Another study revealed that DDB2 over-expression within a cancer cell line led to higher cisplatin sensitivity through an increase in apoptosis [46]. Recently, Stergiou analysed the effects of an uncharacterized XPC mutation in $C$. elegans and showed that its capacity to trigger apoptosis following a genotoxic stress was reduced [47]. In our study, DDB2 and XPC could be specifically upregulated in the $A \beta$-secreting cell line, in response to the $\mathrm{H}_{2} \mathrm{O}_{2}$-induced DNA damage. It may thus be proposed that this process results in increased apoptosis. Indeed, Bagchi and Raychauduri [43] proposed that DDB2 could be a sensor of unrepaired DNA damage when their level is too high compared to the repair capacity of the cell. Finally, an interesting and very recent study demonstrates that p53-inducible DDB2 promotes apoptosis by mediating p21 degradation after ultraviolet UV-induced DNA damage [48]. As a matter of fact, neurons in AD exhibit a large amount of accumulated and unrepaired DNA damage over time [49,50], and DDB2 and/or XPC, through their sensor activity might further drive neurons into apoptosis.

\section{Experimental Section}

\subsection{Cell Lines and Culture Conditions}

The SK-SHSY5Y neuroblastoma cell line was either transfected with the pcDNA3 plasmid alone (mock cell line) or with pcDNA3 bearing the transgene corresponding to the Swedish mutation of APP (APP751-expressing cell line). The two cell lines were a gift from Luc Buée [51,52]. The cells were grown in Dulbecco's modified Eagle's medium/Glutamax ${ }^{\mathrm{TM}}$ supplemented with $10 \%$ fetal calf serum (FCS), $1 \mathrm{mM}$ non-essential amino acids, 1\% penicillin/streptomycin (Invitrogen, Saint-Aubin, France) and $400 \mu \mathrm{g} / \mathrm{mL} \mathrm{G418} \mathrm{(selection} \mathrm{for} \mathrm{cells} \mathrm{expressing} \mathrm{APP751} \mathrm{or} \mathrm{the} \mathrm{mock} \mathrm{vector)} \mathrm{in} \mathrm{a} 5 \% \mathrm{CO}_{2}$ humidified incubator at $37^{\circ} \mathrm{C}$.

\subsection{UVC-Induced Cytotoxicity Measurements}

The mock and APP751-expressing cell lines were plated in $60 \mathrm{~mm}$ Petri dishes in $4 \mathrm{~mL}$ of medium and incubated at $37{ }^{\circ} \mathrm{C}$ for $48 \mathrm{~h}$. The medium was removed, kept in falcons (Beckton Dickinson, POnt-De-Claix, France) and replaced by PBS containing $\mathrm{Ca}^{2+}$ and $\mathrm{Mg}^{2+}$ (Sigma, Saint-Quentin-Fallavier, France). Petri dishes were irradiated in triplicate at $5,10,15$ or $20 \mathrm{~J} / \mathrm{m}^{2}$ of UVC radiations $(254 \mathrm{~nm})$. A triplicate of non-irradiated dishes was also used as a control. PBS was then removed and the conditioned medium redistributed in its appropriated dish. Cells were then incubated for another $24 \mathrm{~h}$ at $37^{\circ} \mathrm{C}$. At the end of the incubation, cytotoxicity was assessed using a modified MTT (Sigma) assay. Briefly, $400 \mu \mathrm{L}$ of MTT $(5 \mathrm{mg} / \mathrm{mL})$ in phosphate-buffered saline (PBS, Invitrogen) was added to each well. The medium was removed $2 \mathrm{~h}$ later, $3 \mathrm{~mL}$ of DMSO (Sigma) was added to dissolve the produced formazan, and the absorbance was read at $565 \mathrm{~nm}$ using a Multiskan RC microplate spectrophotometer (Labsystems, Nantes, France). The absorbance at $565 \mathrm{~nm}$ was proportional to the number of viable cells, and survival was calculated as the percentage of specific viability.

\subsection{Long-Term Toxicity of UVC}

To study the long-term toxicity of UVC, we performed an in vitro colony-forming assay, which is an in vitro cell survival assay, based on the ability of a single cell to grow into a colony after 2 weeks. 
Mock and APP751-expressing cell lines were plated $35 \mathrm{~mm}$ Petri dishes $\left(10 \mathrm{cells} / \mathrm{cm}^{2}\right)$ in $2 \mathrm{~mL}$ of medium and grown for $48 \mathrm{~h}$ at $37^{\circ} \mathrm{C}$. Cells were then irradiated in PBS containing $\mathrm{Ca}^{2+}$ and $\mathrm{Mg}^{2+}$ at 5, 10,15 or $20 \mathrm{~J} / \mathrm{m}^{2}$ of $\mathrm{UVC}$ radiation, and the preserved cell media replaced in its appropriated dish. Cells were grown for additional 12 days, and their media were changed every three-days. Then $500 \mu \mathrm{L}$ of a crystal violet solution $(0.5 \% \mathrm{p} / \mathrm{v})$ in methanol/ $\mathrm{H}_{2} \mathrm{O} 1: 1$ was applied for $10 \mathrm{~min}$ at room temperature to reveal the living cells. The dishes were then rinsed and the visible colonies counted.

\subsection{Preparation of Frozen Pellets}

Mock and APP751-transfected cell lines were plated in $75-\mathrm{cm}^{2}$ flasks (Becton Dickinson Biosciences, Pont-de-Claix, France) and incubated for $48 \mathrm{~h}$ before treatment in the presence of G418. Each cell line was then treated with the amount of either $\mathrm{H}_{2} \mathrm{O}_{2}$ corresponding to the $\mathrm{IC}_{10}$ of the mock cell line by adding $1.5 \mathrm{~mL}$ of the $11 \mathrm{X}$-concentrated solutions to the $15 \mathrm{~mL}$ of culture media already present in the flask. In control flasks, $1.5 \mathrm{~mL}$ of $\mathrm{H}_{2} \mathrm{O}$ alone was added. Cell lines were incubated for an additional $24 \mathrm{~h}$ and then collected by trypsinization, recovered, counted and pelleted by centrifugation at $300 \times \mathrm{g}$ for $10 \mathrm{~min}$. For UVC-associated experiments, Mock and APP751-expressing cells were plated in $100 \mathrm{~mm}$ petri dishes and incubated for $48 \mathrm{~h}$ before irradiation. Then, the culture medium was removed, kept aside and replaced by PBS containing $\mathrm{Mg}^{2+}$ and $\mathrm{Ca}^{2+}$. Cells were irradiated at $5 \mathrm{~J} / \mathrm{cm}^{2}$ and either collected right after or the old culture media was added back to the petri dished to collect different kinetics points.

For both kinds of stress, the required amount of cells for each appropriate experiment was resuspended in FCS supplemented with $10 \%$ DMSO, gently frozen to $-80{ }^{\circ} \mathrm{C}$ and stored in liquid nitrogen or dry-frozen.

\subsection{DNA Extraction and Digestion}

DNA extraction and digestion were performed as described previously [53]. Briefly, frozen cell pellets were resuspended in lysis buffer A $(320 \mathrm{mM}$ sucrose, $5 \mathrm{mM} \mathrm{MgCl}, 10 \mathrm{mM}$ Tris, $0.1 \mathrm{mM}$ deferoxamine $\mathrm{pH} 7.5,1 \%$ Triton $\mathrm{X}-100$ ). The nuclei were then pelleted by centrifugation at $1500 \times g$ for $5 \mathrm{~min}$ and washed by $750 \mu \mathrm{L}$ of buffer A. Then buffer B (10 mM Tris, $5 \mathrm{mM}$ EDTA-Na2, $0.15 \mathrm{mM}$ deferoxamine, $\mathrm{pH} 8.0$ ) and SDS 10\% was applied to allow the nuclei lysis. After adding a mixture of RNase A and RNase T1, the samples were incubated for $15 \mathrm{~min}$ at $56{ }^{\circ} \mathrm{C}$. A second incubation step at $37^{\circ} \mathrm{C}$ for $1 \mathrm{~h}$ with Qiagen protease was next performed. The subsequent additions of a solution of $\mathrm{NaI}$ (7.6 M NaI, $40 \mathrm{mM}$ Tris, $20 \mathrm{mM}$ EDTA-Na2, $0.3 \mathrm{mM}$ deferoxamine, $\mathrm{pH} \mathrm{8.0)}$ and 100\% isopropanol allowed DNA precipitation. Two washes were performed with first $40 \%$ isopropanol and then $70 \%$ EtOH. Finally, DNA was solubilised $0.1 \mathrm{mM}$ deferroxiamine and DNA digestion was launched by a $2 \mathrm{~h}$ at $37{ }^{\circ} \mathrm{C}$ incubation with nuclease P1, phosphodiesterase II and buffer $10 \times(200 \mathrm{mM}$ succinic acid, $100 \mathrm{mM} \mathrm{CaCl}_{2}$, pH 6.0) altogether. Then, a second digestion step was realized with phosphodiesterase I and alkaline phosphatase in alkaline phosphatase buffer $10 \times(500 \mathrm{mM}$ Tris, $1 \mathrm{mM}$ EDTA, $\mathrm{pH}$ 8.0) for $2 \mathrm{~h}$ at $37{ }^{\circ} \mathrm{C}$. At last, the solution was neutralized with $0.1 \mathrm{mM} \mathrm{HCl}$ and centrifuged for $5 \mathrm{~min}$ at $5000 \times g$. The supernatant was collected for analysis by HPLC-MS/MS. 


\subsection{Analysis of DNA Lesions (HPLC-MS/MS)}

The digested sample was then injected onto an HPLC system consisting in a Agilent series 1100 system equipped with a Uptisphere ODB reverse phase column $(2 \times 250 \mathrm{~mm} \mathrm{ID}$, particle size $5 \mu \mathrm{m}$; Interchim, Montluçon, France). The mobile phase was a gradient of acetonitrile in a $2 \mathrm{mM}$ aqueous solution of triethylammonium acetate. A UV detector set at $260 \mathrm{~nm}$ was used to quantify normal nucleosides in order to determine the amount of analyzed DNA. The HPLC flow was then directed toward an API 3000 electrospray triple quadrupole mass spectrometer operating in the negative ionization mode. The detection of TT-CPD, TC-CPD or CT-CPD was performed in the "multiple reaction monitoring" mode. Two fragmentations were monitored: $\left.545[\mathrm{M}-\mathrm{H}]^{-}\right) \rightarrow 447[\mathrm{M}$-dehydrated 2-deoxyribose- $\mathrm{H}]^{-}$) and $\left.545[\mathrm{M}-\mathrm{H}]^{-}\right) \rightarrow 195$ [phosphorylated 2-deoxyribose-H] $]^{-}$). External calibration was achieved for both detectors using authentic compounds.

\subsection{Gene Expression Analysis}

\subsection{1. mRNA Extraction and Quality Analysis}

Total RNA was extracted from each sample with the GenElute mammalian total RNA miniprep kit (Sigma). RNA integrity was assessed verifying the A260/280 nm absorbance ratio between 1.7 and 2.1 and then using native gel electrophoresis. An amount of $500 \mathrm{ng}$ per sample in native agarose gel loading buffer ( $15 \%$ ficoll, $0.25 \%$ xylene cyanol, $0.25 \%$ bromophenol blue) were loaded on $1 \%$ agarose gels in TBE (89 mM Tris-HCl pH 7.8, $89 \mathrm{mM}$ borate, $2 \mathrm{mM}$ EDTA) with $0.5 \mu \mathrm{g} / \mathrm{mL}$ ethidium bromide (Sigma) added to the gel. The gel was then run at 5-6 V/cm measured between the electrodes. Total RNA was considered as intact when 2 sharp 28S and 18S rRNA bands were visualized, with a 2:1 (28S:18S) ratio in term of intensity.

\subsubsection{Reverse Transcription}

Total RNA was reverse transcribed, using Superscript II Reverse Transcriptase ${ }^{\mathrm{TM}}$ (Invitrogen) according to the manufacturer's protocol. Briefly, $2 \mu \mathrm{g}$ of total RNA were heat with $100 \mathrm{ng}$ of Random Hexamers Primers (Promega SARL, Charbonnières, France) and $10 \mathrm{nmol}$ of a dNTPs mix (Sigma) for 5 min at $70{ }^{\circ} \mathrm{C}$ and quick chilled on ice. Then $5 \mathrm{X}$ first-strand buffer to a final concentration of $1 \mathrm{X}$, $0.1 \mathrm{M}$ DTT and $45 \mathrm{U}$ of ribonuclease inhibitor (Sigma) were added to the mixture and incubated for 2 min at $25^{\circ} \mathrm{C} .200 \mathrm{U}$ of Superscript II Reverse Transcriptase ${ }^{\mathrm{TM}}$ were finally added to the mixture and incubated first for $10 \mathrm{~min}$ at $25^{\circ} \mathrm{C}$ and next for $50 \mathrm{~min}$ at $42{ }^{\circ} \mathrm{C}$. The reaction was stopped by heating for $15 \mathrm{~min}$ at $70^{\circ} \mathrm{C}$.

\subsubsection{Real Time Quantitative PCR}

Gene specific Oligonucleotide primers (Table 1) were designed using Primer3-web 0.4.0 (http://primer3.sourceforge.net) and obtained from a commercial supplier (Eurogentec SARL, Angers, France). Quantitative PCR (qPCR) was performed in a MX3005p Multiplex Quantitative PCR system (Stratagene, La Jolla, CA, USA) using MESA Blue qPCR ${ }^{\mathrm{TM}}$ Mastermix Plus for SYBR ${ }^{\circledR}$ Assay_Low Rox (Eurogentec, Angers, France). Quantitative PCR reactions were carried out in triplicate in $25 \mu \mathrm{L}$ 
reaction volumes containing $200 \mathrm{nM}$ forward and reverse primers and $20 \mathrm{ng}$ template using the following program: $5 \mathrm{~min}$ at $95^{\circ} \mathrm{C}$, and 40 cycles of $15 \mathrm{~s}$ at $95{ }^{\circ} \mathrm{C}, 20 \mathrm{~s}$ at $55^{\circ} \mathrm{C}$ and $40 \mathrm{~s}$ at $72{ }^{\circ} \mathrm{C}$ with fluorescence acquisition at the end of the $55^{\circ} \mathrm{C}$ primer annealing step. The integrity of amplification indicated by a single melt peak for each product was verified by a dissociation curve analysis at $95{ }^{\circ} \mathrm{C}$ for $1 \mathrm{~min}, 55^{\circ} \mathrm{C}$ for $30 \mathrm{~s}$ and $95{ }^{\circ} \mathrm{C}$ for $30 \mathrm{~s}$ with fluorescence acquisition at all points from 55 to $95{ }^{\circ} \mathrm{C}$. The built in amplification-based proprietary algorithm (Stratagene) was used to set the fluorescence threshold value. This algorithm determines the portion of the amplification plots where all of the data curves display an exponential increase in fluorescence, and calculates the threshold value that minimizes the standard deviation in $C_{\mathrm{t}}$ values for each replicate set at a point which falls within $32.5 \%$ of the fluorescence shift for all the curves. The number of cycles $\left(C_{\mathrm{t}}\right)$ at which the amplification-corrected normalized fluorescence $(\mathrm{dRn})$ for each reaction crossed the threshold value was exported to Excel (Microsoft, Redmond, WA, USA) for further analysis.

Table 1. Primer sets used for real time quantitative PCR.

\begin{tabular}{ccccccc}
\hline Name & $\begin{array}{c}\text { GeneBank } \\
\text { Entry }\end{array}$ & $\begin{array}{c}\text { Forward Primer } \\
\text { Sequence }\end{array}$ & $\begin{array}{c}\text { Tm } \\
\left({ }^{\circ} \mathbf{C}\right)\end{array}$ & $\begin{array}{c}\text { Reverse Primer } \\
\text { Sequence }\end{array}$ & $\begin{array}{c}\text { Tm } \\
\left({ }^{\circ} \mathbf{C}\right)\end{array}$ & $\begin{array}{c}\text { Product } \\
\text { Size (bp) }\end{array}$ \\
\hline XPA & NM_000380.3 & gcagccccaaagataattga & 60.04 & tggcaaatcaaagtggttca & 60.09 & 183 \\
XPC & NM_004628.4 & ccatgaggacacacacaagg & 60 & tccaatgaaccacttcacca & 59.94 & 187 \\
DDB1 & NM_001923.3 & aacagagtggcgagagcatt & 60.02 & tcaatgacatgcagctcctc & 59.95 & 223 \\
DDB2 & NM_000107.2 & tcaaggacaaacccacttc & 59.94 & gtgaccaccattcggctact & 60 & 226 \\
XPD & NM_000400.3 & gctggacatctaccccaaga & 60.07 & ccggatcacagcaatatcct & 59.92 & 166 \\
XPB & NM_000122.1 & gcggcagagattcttggtag & 59.98 & ggccccagacatagaactca & 60.07 & 235 \\
ERCC1 & NM_202001.1 & ttgtccaggtggatgtgaaa & 59.94 & gctggtttctgctcataggc & 59.98 & 151 \\
PCNA & NM_002592.2 & ggctctagcetgacaaatgc & 59.98 & gcctccaacacttcttgag & 59.84 & 224 \\
\hline
\end{tabular}

\subsubsection{Validation of Stably Expressed Housekeeping Genes}

We tested 3 different housekeeping/reference genes in order to use them all for an optimal normalization of the target genes. S18, GAPDH and CycloB were amplified in triplicate in each sample and condition on a same qPCR run. Corresponding $C_{\mathrm{t}}$ were exported to BestKeeper [54], an Excel-based pair wise correlation tool that analyses variability in the expression in individual genes (SD and coefficient of variation) and generates a weighted expression index, the BestKeeper Index, in the form of a geometric mean of $C_{\mathrm{t}}$ values from several candidate reference genes. Then, correlation between each candidate and the index is calculated, describing the relation between the index and the contributing candidate reference gene by the Pearson correlation coefficient $(r)$, coefficient of determination $\left(r^{2}\right)$ and the $p$-value. Individually S18, GAPDH and CycloB showed an SD smaller than 1. The analysis of Pearson coefficient correlation showed a strong correlation for all candidates. Individual SD and Pearson coefficient correlation of the 3 genes were tested in each PCR run and were always satisfying.

\subsection{5. mRNA Quantification and Statistical Analyses}

Targeted genes' mRNA expression was normalized to the expressed housekeeping genes S18, GAPDH and CycloB using Relative Expression Software Tool 2006 [55], which uses the pair-wise 
fixed reallocation randomization test as statistical models. Corresponding $p$-values were analyzed to evaluate the significance of expression ratio after each PCR run, but we used the Student's $t$-test for comparing the mean of expression ratios between the two conditions after three to seven qPCR runs, equivalent to three to seven biological replicates, for each tested target gene.

\subsection{DNA Repair Assays}

The alkaline single-cell gel electrophoresis assay was used to measure DNA repair capacity of cell extracts, which involves slight changes of the precedent version. Briefly, frozen pellets of LnCap $10 \mathrm{~J} / \mathrm{cm}^{2}$ UVC-irradiated were embedded in low-melt agarose, spread on microscope slides previously coated with one layer of normal agarose, gelled on ice and immersed in lysis solution overnight at $4{ }^{\circ} \mathrm{C}$. The slides were neutralized and equilibrated in the Reaction buffer digestion buffer ( 3 times $5 \mathrm{~min}$ in $40 \mathrm{mM}$ HEPES, 0.1 M KCl, $0.5 \mathrm{mM}$ EDTA, $2 \mathrm{mg} / \mathrm{mL}$ BSA pH 8; Sigma). Frozen pellets of Mock and APP751-expressing cells treated or not by $\mathrm{CuSO}_{4}$ and $\mathrm{H}_{2} \mathrm{O}_{2}\left(3 \times 10^{6}\right.$ cells per condition) were centrifuged at $1400 \mathrm{rpm}$ for $5 \mathrm{~min}$ at $4{ }^{\circ} \mathrm{C}$, washed once in cold-PBS and resuspended in Extraction Buffer (45 mM HEPES, 0.4 M KCl, $1 \mathrm{mM}$ EDTA, 10\% Glycerol, $0.1 \mathrm{mM}$ DTT, 0.25X Triton; Sigma). The mixture was then vortexed for $30 \mathrm{~s}$, incubated for $5 \mathrm{~min}$ on ice and centrifuged at $14,000 \times \mathrm{g}$ for $5 \mathrm{~min}$ at $4{ }^{\circ} \mathrm{C}$. The supernatant was then added to a cold volume of Reaction Buffer (1:5). Incubation with these freshly prepared cell extracts $\left(50 \mu \mathrm{L}\right.$ per slide) was performed for 30 min at $37^{\circ} \mathrm{C}$. Digestion with Fpg $(1.7 \mu \mathrm{g} / \mathrm{mL}, 100 \mu \mathrm{L}$ per slide) was used as positive controls and negative controls were mock-treated with a 1:5 mix of Extraction and Reaction Buffer. After digestion, the slides were transferred into the electrophoresis tank filled with electrophoresis buffer pre-chilled at $4{ }^{\circ} \mathrm{C}$. The slides were left at room temperature for $30 \mathrm{~min}$ and electrophoresis was subsequently accomplished for $30 \mathrm{~min}$ at $25 \mathrm{~V}$ and $300 \mathrm{~mA}$. After migration, the slides were rinsed in the neutralization buffer ( $5 \mathrm{~min}$, room temperature) and stained with ethidium bromide.

We used the Comet Assay IV software (Perceptive Instruments, Suffolk, UK) to analyse the slides. Fifty randomly selected nuclei were scored by slide and triplicate slides were processed for each experimental point. The extent of damage was evaluated by the Tail DNA value defined as the percentage of DNA in the tail of the comet. Significance of differences between one sample and another was determined by Student's $t$-test.

\subsection{Cell Nuclear Extracts}

Nuclear extracts were prepared as already described [56]. Briefly, thawed cells were washed twice in ice-cold PBS, suspended in $1 \mathrm{~mL}$ of ice-cold buffer A (10 mM HEPES pH 7.9, $1.5 \mathrm{mM} \cdot \mathrm{MgCl}_{2}$, $10 \mathrm{mM} \cdot \mathrm{KCl}, 0.01 \%$ Triton X-100, $0.5 \mathrm{mM} \mathrm{DTT,} 0.5 \mathrm{mM} \mathrm{PMSF}$ ) and left on ice for $20 \mathrm{~min}$. Cytoplasm membrane lysis was completed by vortexing the tube for $30 \mathrm{~s}$. Lysis completion was controlled by trypan blue exclusion and nuclei were recovered by centrifugation $5 \mathrm{~min}$ at $5000 \mathrm{rpm}$ at $4{ }^{\circ} \mathrm{C}$. They were then suspended in $25 \mu \mathrm{L}$ of ice-cold buffer B (10 mM HEPES pH 7.9, $1.5 \mathrm{mM} \mathrm{MgCl} 2,400 \mathrm{mM} \mathrm{KCl}, 0.2 \mathrm{mM}$ EDTA, 25\% glycerol, $0.5 \mathrm{mM}$ DTT, anti-proteases (Complete-mini, Roche, Meylan, France) and 0.5 mM PMSF). Nuclear membranes were lysed for $20 \mathrm{~min}$ on ice, and two cycles of freezing-thawing at -80 and $4{ }^{\circ} \mathrm{C}$ respectively. The extracts were cleared by centrifugation for $10 \mathrm{~min}$ at $13,000 \mathrm{rpm}$ at $4{ }^{\circ} \mathrm{C}$. The supernatant was recovered and stored 
frozen in $10 \mu \mathrm{L}$ aliquots at $-80{ }^{\circ} \mathrm{C}$. Protein content was determined using the BCA kit (Interchim, Montluçon, France). Typical protein content was $1 \mathrm{mg} / \mathrm{mL}$.

\section{Conclusions}

In summary, we observed that, as for BER, the neurotoxic peptide A $\beta$ interferes with NER. However, the effects are completely different. In a previous work using the same cellular model, we have shown that $A \beta$ decreases BER activities and expression of a wide range of BER-associated genes, both at the basal level and in response to an oxidative stress. The present study reveals a drastically different impact of $A \beta$ on NER. First, only two genes are affected by oxidative stress in the presence of $\mathrm{A} \beta$, and in contrast to BER, are over expressed. Interestingly, the protein products of these two genes are also involved in the induction of apoptosis. This observation combined with the now well-established accumulation of DNA damage resulting from increasing oxidative insult and reduced BER repair, could explain why neurons easily undergo apoptosis in AD patients. Improving global DNA repair might therefore be a new strategy to prevent neuronal death in $\mathrm{AD}$ patients.

\section{Acknowledgments}

We are grateful to Luc Buée, Nicolas Sergeant and Malika Hamdane (INSERM U 837, Lille, France) for the APP751 and Mock cell lines. This work was supported by the university Grenoble Alpes and the CEA. Some methods have been developed through the LODORA project, which is funded by the French National Research Agency (ANR) and by the PRIMES LABEX (ANR-11-LABX-0063) of Universite de Lyon, within the program "Investissements d'Avenir" (ANR-11-IDEX-0007) operated by the French National Research Agency (ANR). Anne Forestier was supported by a grant from the Ministry of Higher Education and Research.

\section{Author Contributions}

Anne Forestier: performed research, analyzed data, wrote the paper, Thierry Douki: performed research, Viviana De Rosa: performed research, David Béal: performed research, Walid Rachidi: designed research, analyzed data, wrote the paper the paper.

\section{Conflicts of Interest}

The authors declare no conflict of interest.

\section{References}

1. Mattson, M.P. Pathways towards and away from Alzheimer's disease. Nature 2004, 430, 631-639.

2. Barzilai, A. DNA damage, neuronal and glial cell death and neurodegeneration. Apoptosis 2010, 15, 1371-1381.

3. Jacobsen, E.; Beach, T.; Shen, Y.; Li, R.; Chang, Y. Deficiency of the Mre11 DNA repair complex in Alzheimer's disease brains. Brain Res. Mol. Brain Res. 2004, 128, 1-7. 
4. Lovell, M.A.; Markesbery, W.R. Oxidative DNA damage in mild cognitive impairment and late-stage Alzheimer's disease. Nucleic Acids Res. 2007, 35, 7497-7504.

5. Shao, C.; Xiong, S.; Li, G.M.; Gu, L.; Mao, G.; Markesbery, W.R.; Lovell, M.A., Altered 8-oxoguanine glycosylase in mild cognitive impairment and late-stage Alzheimer's disease brain. Free Radic. Biol. Med. 2008, 45, 813-819.

6. Weissman, L.; Jo, D.G.; Sorensen, M.M.; de Souza-Pinto, N.C.; Markesbery, W.R.; Mattson, M.P.; Bohr, V.A. Defective DNA base excision repair in brain from individuals with Alzheimer's disease and amnestic mild cognitive impairment. Nucleic Acids Res. 2007, 35, $5545-5555$.

7. Canugovi, C.; Shamanna, R.A.; Croteau, D.L.; Bohr, V.A. Base excision DNA repair levels in mitochondrial lysates of Alzheimer's disease. Neurobiol. Aging 2014, 35, 1293-1300.

8. Lillenes, M.S.; Stoen, M.; Gomez-Munoz, M.; Torp, R.; Gunther, C.C.; Nilsson, L.N.; Tonjum, T. Transient OGG1, APE1, PARP1 and Polbeta expression in an Alzheimer's disease mouse model. Mech. Ageing Dev. 2013, 134, 467-477.

9. Bucholtz, N.; Demuth, I. DNA-repair in mild cognitive impairment and Alzheimer's disease. DNA Repair 2013, 12, 811-816.

10. Leandro, G.S.; Lobo, R.R.; Oliveira, D.V.; Moriguti, J.C.; Sakamoto-Hojo, E.T. Lymphocytes of patients with Alzheimer's disease display different DNA damage repair kinetics and expression profiles of DNA repair and stress response genes. Int. J. Mol. Sci. 2013, 14, 12380-12400.

11. Sykora, P.; Misiak, M.; Wang, Y.; Ghosh, S.; Leandro, G.S.; Liu, D.; Tian, J.; Baptiste, B.A.; Cong, W.N.; Brenerman, B.M.; et al. DNA polymerase beta deficiency leads to neurodegeneration and exacerbates Alzheimer disease phenotypes. Nucleic Acids Res. 2015, 43, 943-959.

12. Krokan, H.E.; Nilsen, H.; Skorpen, F.; Otterlei, M.; Slupphaug, G. Base excision repair of DNA in mammalian cells. FEBS Lett. 2000, 476, 73-77.

13. Wood, R.D. Nucleotide excision repair in mammalian cells. J. Biol. Chem. 1997, 272, 23465-23468.

14. Fousteri, M.; Mullenders, L.H. Transcription-coupled nucleotide excision repair in mammalian cells: Molecular mechanisms and biological effects. Cell Res. 2008, 18, 73-84.

15. Shrivastav, M.; de Haro, L.P.; Nickoloff, J.A. Regulation of DNA double-strand break repair pathway choice. Cell Res. 2008, 18, 134-147.

16. Kraemer, K.H.; Patronas, N.J.; Schiffmann, R.; Brooks, B.P.; Tamura, D.; di Giovanna, J.J. Xeroderma pigmentosum, trichothiodystrophy and Cockayne syndrome: A complex genotype-phenotype relationship. Neuroscience 2007, 145, 1388-1396.

17. Rass, U.; Ahel, I.; West, S.C. Defective DNA repair and neurodegenerative disease. Cell 2007, 130, 991-1004.

18. Nardo, T.; Oneda, R.; Spivak, G.; Vaz, B.; Mortier, L.; Thomas, P.; Orioli, D.; Laugel, V.; Stary, A.; Hanawalt, P.C.; et al. A UV-sensitive syndrome patient with a specific CSA mutation reveals separable roles for CSA in response to UV and oxidative DNA damage. Proc. Natl Acad. Sci. USA 2009, 106, 6209-6214.

19. Nouspikel, T. Nucleotide excision repair and neurological diseases. DNA Repair 2008, 7, 1155-1167. 
20. Forestier, A.; Douki, T.; Sauvaigo, S.; Rosa, V.D.; Demeilliers, C.; Rachidi, W. Alzheimer's disease-associated neurotoxic Peptide amyloid-beta impairs base excision repair in human neuroblastoma cells. Int. J. Mol. Sci. 2012, 13, 14766-14787.

21. Staropoli, J.F. Tumorigenesis and neurodegeneration: Two sides of the same coin? Bioessays 2008, 30, 719-727.

22. Markesbery, W.R. The role of oxidative stress in Alzheimer disease. Arch. Neurol. 1999, 56, 1449-1452.

23. Moreira, P.I.; Nunomura, A.; Nakamura, M.; Takeda, A.; Shenk, J.C.; Aliev, G.; Smith, M.A.; Perry, G. Nucleic acid oxidation in Alzheimer disease. Free Radic. Biol. Med. 2008, 44, 1493-1505.

24. Markesbery, W.R. Oxidative stress hypothesis in Alzheimer's disease. Free Radic. Biol. Med. 1997, 23, 134-147.

25. Dusinska, M.; Dzupinkova, Z.; Wsolova, L.; Harrington, V.; Collins, A.R. Possible involvement of XPA in repair of oxidative DNA damage deduced from analysis of damage, repair and genotype in a human population study. Mutagenesis 2006, 21, 205-211.

26. D’Errico, M.; Parlanti, E.; Teson, M.; de Jesus, B.M.; Degan, P.; Calcagnile, A.; Jaruga, P.; Bjoras, M.; Crescenzi, M.; Pedrini, A.M.; et al. New functions of XPC in the protection of human skin cells from oxidative damage. EMBO J. 2006, 25, 4305-4315.

27. Reardon, J.T.; Bessho, T.; Kung, H.C.; Bolton, P.H.; Sancar, A. In vitro repair of oxidative DNA damage by human nucleotide excision repair system: Possible explanation for neurodegeneration in xeroderma pigmentosum patients. Proc. Natl Acad. Sci. USA 1997, 94, 9463-9468.

28. Yang, W. Poor base stacking at DNA lesions may initiate recognition by many repair proteins. DNA Repair 2006, 5, 654-666.

29. Bernardes de Jesus, B.M.; Bjoras, M.; Coin, F.; Egly, J.M. Dissection of the molecular defects caused by pathogenic mutations in the DNA repair factor XPC. Mol. Cell. Biol. 2008, 28, 7225-7235.

30. Low, G.K.; Fok, E.D.; Ting, A.P.; Hande, M.P. Oxidative damage induced genotoxic effects in human fibroblasts from Xeroderma Pigmentosum group A patients. Int. J. Biochem. Cell Biol. 2008, 40, 2583-2595.

31. Dianov, G.; Bischoff, C.; Piotrowski, J.; Bohr, V.A. Repair pathways for processing of 8-oxoguanine in DNA by mammalian cell extracts. J. Biol. Chem. 1998, 273, 33811-33816.

32. De Waard, H.; de Wit, J.; Andressoo, J.O.; van Oostrom, C.T.; Riis, B.; Weimann, A.; Poulsen, H.E.; van Steeg, H.; Hoeijmakers, J.H.; van der Horst, G.T. Different effects of CSA and CSB deficiency on sensitivity to oxidative DNA damage. Mol. Cell. Biol. 2004, 24, 7941-7948.

33. D’Errico, M.; Parlanti, E.; Teson, M.; Degan, P.; Lemma, T.; Calcagnile, A.; Iavarone, I.; Jaruga, P.; Ropolo, M.; Pedrini, A.M.; et al. The role of CSA in the response to oxidative DNA damage in human cells. Oncogene 2007, 26, 4336-4343.

34. Rolig, R.L.; McKinnon, P.J. Linking DNA damage and neurodegeneration. Trends Neurosci. 2000, 23, 417-424.

35. Hermon, M.; Cairns, N.; Egly, J.M.; Fery, A.; Labudova, O.; Lubec, G. Expression of DNA excision-repair-cross-complementing proteins p80 and p89 in brain of patients with down Syndrome and Alzheimer's disease. Neurosci. Lett. 1998, 251, 45-48. 
36. Wang, X.W.; Vermeulen, W.; Coursen, J.D.; Gibson, M.; Lupold, S.E.; Forrester, K.; Xu, G.; Elmore, L.; Yeh, H.; Hoeijmakers, J.H.; et al. The XPB and XPD DNA helicases are components of the p53-mediated apoptosis pathway. Genes Dev. 1996, 10, 1219-1232.

37. Wang, Y. Bulky DNA lesions induced by reactive oxygen species. Chem. Res. Toxicol. 2008, 21, 276-281.

38. Robbins, J.H.; Polinsky, R.J.; Moshell, A.N. Evidence that lack of deoxyribonucleic acid repair causes death of neurons in xeroderma pigmentosum. Ann. Neurol. 1983, 13, 682-684.

39. Bergeron, F.; Auvre, F.; Radicella, J.P.; Ravanat, J.L. HO• radicals induce an unexpected high proportion of tandem base lesions refractory to repair by DNA glycosylases. Proc. Natl Acad. Sci. USA 2010, 107, 5528-5533.

40. Catala, A. Lipid peroxidation of membrane phospholipids generates hydroxy-alkenals and oxidized phospholipids active in physiological and/or pathological conditions. Chem. Phys. Lipids 2009, 157, 1-11.

41. Sepe, S.; Payan-Gomez, C.; Milanese, C.; Hoeijmakers, J.H.; Mastroberardino, P.G. Nucleotide excision repair in chronic neurodegenerative diseases. DNA Repair 2013, 12, 568-577.

42. Tang, J.; Chu, G. Xeroderma pigmentosum complementation group $\mathrm{E}$ and UV-damaged DNA-binding protein. DNA Repair 2002, 1, 601-616.

43. Bagchi, S.; Raychaudhuri, P. Damaged-DNA binding protein-2 drives apoptosis following DNA damage. Cell Div. 2010, 5, doi:10.1186/1747-1028-5-3.

44. Stoyanova, T.; Roy, N.; Kopanja, D.; Bagchi, S.; Raychaudhuri, P. DDB2 decides cell fate following DNA damage. Proc. Natl Acad. Sci. USA 2009, 106, 10690-10695.

45. Santos, N.A.; Catao, C.S.; Martins, N.M.; Curti, C.; Bianchi, M.L.; Santos, A.C. Cisplatin-induced nephrotoxicity is associated with oxidative stress, redox state unbalance, impairment of energetic metabolism and apoptosis in rat kidney mitochondria. Arch. Toxicol. 2007, 81, 495-504.

46. Barakat, B.M.; Wang, Q.E.; Han, C.; Milum, K.; Yin, D.T.; Zhao, Q.; Wani, G.; Arafa el, S.A.; El-Mahdy, M.A.; Wani, A.A. Overexpression of DDB2 enhances the sensitivity of human ovarian cancer cells to cisplatin by augmenting cellular apoptosis. Int. J. Cancer 2010, 127, 977-988.

47. Stergiou, L.; Eberhard, R.; Doukoumetzidis, K.; Hengartner, M.O. NER and HR pathways act sequentially to promote UV-C-induced germ cell apoptosis in Caenorhabditis elegans. Cell Death Differ. 2011, 18, 897-906.

48. Li, H.; Zhang, X.-P.; Liu, F. Coordination between p21 and DDB2 in the Cellular Response to UV Radiation. PLOS ONE 2013, 8, e80111.

49. Nouspikel, T.; Hanawalt, P.C. When parsimony backfires: Neglecting DNA repair may doom neurons in Alzheimer's disease. Bioessays 2003, 25, 168-173.

50. Brasnjevic, I.; Hof, P.R.; Steinbusch, H.W.; Schmitz, C. Accumulation of nuclear DNA damage or neuron loss: Molecular basis for a new approach to understanding selective neuronal vulnerability in neurodegenerative diseases. DNA Repair 2008, 7, 1087-1097.

51. Vingtdeux, V.; Hamdane, M.; Loyens, A.; Gele, P.; Drobeck, H.; Begard, S.; Galas, M.C.; Delacourte, A.; Beauvillain, J.C.; Buee, L.; et al. Alkalizing drugs induce accumulation of amyloid precursor protein by-products in luminal vesicles of multivesicular bodies. J. Biol. Chem. 2007, 282, 18197-18205. 
52. Vingtdeux, V.; Hamdane, M.; Gompel, M.; Begard, S.; Drobecq, H.; Ghestem, A.; Grosjean, M.E.; Kostanjevecki, V.; Grognet, P.; Vanmechelen, E.; et al. Phosphorylation of amyloid precursor carboxy-terminal fragments enhances their processing by a gamma-secretase-dependent mechanism. Neurobiol. Dis. 2005, 20, 625-637.

53. Ravanat, J.L.; Douki, T.; Duez, P.; Gremaud, E.; Herbert, K.; Hofer, T.; Lasserre, L.; Saint-Pierre, C.; Favier, A.; Cadet, J. Cellular background level of 8-oxo-7,8-dihydro-2'-deoxyguanosine: An isotope based method to evaluate artefactual oxidation of DNA during its extraction and subsequent work-up. Carcinogenesis 2002, 23, 1911-1918.

54. Pfaffl, M.W.; Tichopad, A.; Prgomet, C.; Neuvians, T.P. Determination of stable housekeeping genes, differentially regulated target genes and sample integrity: BestKeeper-Excel-based tool using pair-wise correlations. Biotechnol. Lett. 2004, 26, 509-515.

55. Pfaffl, M.W.; Horgan, G.W.; Dempfle, L. Relative expression software tool (REST) for group-wise comparison and statistical analysis of relative expression results in real-time PCR. Nucleic Acids Res. 2002, 30, doi:10.1093/nar/30.9.e36.

56. Millau, J.F.; Raffin, A.L.; Caillat, S.; Claudet, C.; Arras, G.; Ugolin, N.; Douki, T.; Ravanat, J.L.; Breton, J.; Oddos, T.; et al. A microarray to measure repair of damaged plasmids by cell lysates. Lab Chip 2008, 8, 1713-1722.

(C) 2015 by the authors; licensee MDPI, Basel, Switzerland. This article is an open access article distributed under the terms and conditions of the Creative Commons Attribution license (http://creativecommons.org/licenses/by/4.0/). 